\title{
Réplica al artículo Periodismo mutante y bastardo*
}

El artículo presentado en el número 22 de la Revista CS (mayo-agosto 2017) por el ilustre periodista, académico y ensayista colombiano Don Omar Rincón, ha sido un fuerte aldabonazo que ha despertado las conciencias críticas de la sociedad acerca del papel activo del periodismo en la sociedad y en la vida cotidiana de las personas. Las furibundas críticas hacia la profesión periodística actual que ha realizado el autor en su trabajo, fueron certeros y afilados dardos que han identificado de forma clara la magnitud, amplitud e importancia de la problemática en la que se encuentra el trabajo del periodista en pleno siglo XXI. En palabras del propio Rincón (2017:27), el símil canino es un magnífico ejemplo para definir el periodismo y a sus profesionales:

El periodista es, ahora, el perro guardián de los empresarios, el capital y los dueños. El periodismo es, apenas, una raza domesticada que se exhibe para el lucimiento de sus amos. Tal vez, ha llegado la hora de hacer otra cosa con esto que amamos y llamamos periodismo; por ejemplo, dejar de ser esa raza domesticada para volver a morder al poder y a las buenas morales empresariales.

Es obvio que el autor muestra una visión pesimista hacia el periodismo, tal como es entendido en la actualidad, pues las estructuras empresariales que giran en torno a esta profesión ya no esconden que simplemente son negocios y lobbies económicos que unen sus tentáculos e influencia con el poder político de forma simbiótica. El ejemplo más nítido de esta situación que Omar Rincón asume como «periodismo guau» (Rincón, 2017: 25), bien podría ser la situación del Grupo Prisa a partir del

* Carta al editor no integrada en ninguna línea de investigación. 
año 2008, una empresa transnacional de origen español con importantes intereses en Colombia.

El otrora poderoso Grupo Prisa, ${ }^{1}$ gran sostenedor de los gobiernos socialistas y temible rival de los gobiernos conservadores en España, cambió su línea editorial a partir de la crisis económica iniciada en 2008, y de su original posición en el espectro del centro-izquierda, se situó en el centro-derecha; debido, en parte, al auxilio económico otorgado de forma indirecta por el gobierno conservador presidido por Mariano Rajoy. Ese tremendo viraje ideológico solo puede ser explicado por las relaciones entre los medios de comunicación, la economía y la política. ${ }^{2}$

Este holding empresarial, el cual es el propietario de la colombiana Caracol Radio, define muy bien la tipología de especies perrunas del periodismo que se analizan en el artículo comentado (Rincón, 2017:26-27), pues este emporio, además de ser una servil y agradecida mascota canina, también se ha involucrado en proyectos fastuosos, modernos y poco rentables como el Huffington Post, periódico digital cuya filial española fue creada en el año 2012. Si bien este diario nunca ha marcado la agenda política ni ha ganado dinero, ha permitido a sus responsables presumir de un supuesto renovado periodismo moral creado para las nuevas generaciones digitales; un concepto similar al «periodismo ovejero» (Rincón, 2017:26) que pontifica de forma constante su objetivo de cambiar su entorno pero, en realidad, no tiene mordiente real.

El diagnóstico de los males del periodismo descrito por Rincón (2017: 20) resume perfectamente la crisis actual de la profesión, lo cual también valdría para entender los vicios más notables que se producen en una empresa de comunicación tan importante como el Grupo Prisa; pues la idea de que la labor periodística hoy en día, presenta de forma deficiente la información debido a motivos únicamente económicos (gustos personales, impacto social e intereses espurios), es certera. La «dictadura del clic» es la que prevalece en el mercado actual, pudiéndose afirmar que la prensa de papel junto a los novelistas y articulistas de opinión, puestos clásicos de los diarios del siglo XX, fueron sustituidos por periódicos digitales, blogs de escaso rigor y exitosos youtubers, siendo la relación entre los viejos y nuevos poderes tirante y compleja.

1. Acrónimo de Promotora de Información Sociedad Anónima. Empresa cotizada en la bolsa de valores española.

2. Por presiones políticas fueron diferentes acreedores del Grupo Prisa (bancos y compañías de telecomunicaciones) los que aceptaron intercambiar deuda por acciones del grupo en una ruinosa operación bursátil que salvó a la empresa de medios de su bancarrota. 
Es por estas razones por lo que el autor considera que el periodismo tradicional ya no tiene cabida en la sociedad del siglo XXI, teniendo que evolucionar éste en una nueva forma de entender esta profesión. Según Rincón (2017:30), el periodismo tiene que caracterizarse por ser «mutante», en el sentido que debe de ser cambiante $\mathrm{y}$ adaptarse continuamente a la sociedad, $\mathrm{y}$ «bastardo», porque debe ser autónomo y no depender de ningún poder establecido; tomándose las narraciones informativas de mezclas elaboradas por el propio sujeto de múltiples fuentes sin identificar (Rincón, 2017:29) tales como la información cuasi infinita que nos proporciona internet.

\section{Consideraciones generales acerca el «periodismo mutante y bastardo»"}

Si bien aprecio y considero que el artículo Periodismo mutante y bastardo es un material valioso y reivindicativo que perfectamente podría ser un eficaz aliciente para iniciar un profundo y necesitado debate acerca de la situación del periodismo en un mundo dominado por las grandes compañías y las redes sociales, ${ }^{3}$ considero que el autor no justifica adecuadamente varias ideas que defiende en su texto, las cuales intentaré, con la mayor objetividad y claridad posible, contra-argumentar a continuación.

\section{La supuesta degradación del periodismo contemporáneo}

El autor aporta testimonios recientes de representantes del sector que afirman que el trabajo del periodismo moderno se fue degradando con el paso de los últimos años (Rincón, 2017: 19-20); una opinión de la que discrepo, pues la orientación hacia el pragmatismo empresarial en contraposición con el rol de periodista investigador independiente, ya era visible a inicios del siglo pasado. Además, a los orígenes de la prensa impresa siempre estuvo evidentemente asociado al sector más pudiente y elitista de la sociedad (los lectores de prensa del siglo XIX eran las personas alfabetizadas que tenían recursos suficientes para consumir tales productos informativos); es decir, el «periodismo señoritero» (Rincón, 2017:26) es tan antiguo como el mismo periodismo.

Además, en los inicios de la prensa impresa, el papel de la política era mucho más claro, creándose muchos diarios con la única finalidad de difundir ideas sociales o

3. Ambos agentes de poder no son excluyentes, véase por ejemplo la fuerza omnímoda que tienen empresas transnacionales norteamericanas del sector TIC como Google o Facebook. 
con el mero objetivo de ser portavoces y defensores de ciertos partidos políticos. Esta prensa política, la cual podemos entender como «periodismo mascota» (Rincón, 2017: 26), proliferó a finales del siglo XIX e inicios del XX, entró en decadencia y desapareció casi por completo a mediados del siglo XX.

Es innegable que los intereses de los partidos políticos y de los dueños de los medios de comunicación se han opuesto constantemente a las obligaciones del periodista como profesional individual, cuyo deber es el de presentar la realidad de forma rigurosa y entendible para su audiencia y no datos amañados o simples especulaciones; y a pesar de todas estas barreras manifiestas, como afirmaba el respetable periodista español Iñaki Gabilondo, para un verdadero profesional dar la noticia debería ser algo innegociable, siendo debatible (por razones de diversa índole), la manera y enfoque de cómo se realiza el tratamiento de la misma.

Por lo dicho anteriormente, ni sería correcto aceptar que lo dicho por el Sr. Gabilondo depende en exclusiva de factores externos ajenos, ni entender que las diversas presiones recibidas por los periodistas son novedosas primicias en este entorno laboral; por lo que de igual manera se debe rechazar la idea de que los periodistas ejercen mal su profesión debido a la mala praxis de los medios de comunicación, los cuales están interesados únicamente en la audiencia y no en la ética (Rincón, 2017:20). El sector del periodismo y sus profesionales siempre apelan, como bien indica Rincón (2017: 21), a factores externos o a una constante crisis para justificar sus males y no para hacer autocrítica, si bien esta situación no es precisamente novedosa, teniendo los agoreros y voceros de la decadencia periodística tanta tradición histórica como escasa capacidad de predicción.

\section{La incongruencia del periodismo mutante}

Rincón (2017:30) defiende el «slow periodismo» como un modelo de trabajo viable y futuro, el cual debería ser también «popular y ciudadano»; una metodología contraria al «periodismo guau» (Rincón, 2017: 25); mas en una sociedad como la actual, en la que la inmediatez de las informaciones que nos proporcionan las tecnologías es más importante que la fiabilidad y validez de las mismas, ¿no se podría pensar que el interés del periodismo por las redes sociales en vez de ser un defecto que evidencia la crisis del periodismo clásico (Rincón, 2017: 19), es una evolución natural de un sector laboral en consonancia con su sociedad?

En estos momentos actuales, la sociedad moderna demanda información rápida e impactante y no datos rigurosos y sesudos, y esto se ha podido evidenciar con las situaciones del Brexit o la victoria de Donald Trump en las elecciones norteame- 
ricanas, aunque la política basada en el populismo es tan antigua como la misma democracia. ${ }^{4}$ Creer que son los medios de comunicación, en exclusiva, los emisores que introducen «estupideces» (Rincón, 2017: 20) con el único afán de lograr más beneficios, es una simplificación fallida en la que caen muchos profesionales.

Esta ingenua relación de causa-efecto es más una simple expresión de rabia y frustración que evidencia un fracaso profesional o empresarial, que una argumentación seria; pues afortunadamente el público en los países democráticos avanzados, puede elegir entre una serie de productos periodísticos muy amplia, y precisamente se escogen los de mayor o peor calidad por causas muy pintorescas y diversas. Las empresas también se adaptan a los intereses de la audiencia y ambos agentes se influyen de forma mutua.

Esta influencia de la sociedad respecto a sus medios informativos, se puede entender de forma muy clara con la evolución producida en los periódicos impresos a su paso al formato digital. En la actualidad compiten productos de calidad de pago con meros blogs de opinión sin ninguna credibilidad, estando el poder de decisión en la sociedad y no en las empresas, teniéndose que esforzar éstas en presentar productos competitivos y llamativos para el público. La visión quietista es más cómoda para el profesional que la autocrítica rigurosa.

En el ámbito de la televisión comercial, un nicho de mercado en el que compiten múltiples canales de diversa gama e intereses, sucede algo similar. En diferentes países y distintas culturas compiten continuamente diferentes programas y es difícil creer que la audiencia escoje siempre los programas éticos y de calidad (lo que puede hacer libremente y no realiza) y repudia los programas amarillistas y sensacionalistas. La televisión ha evolucionado junto a la sociedad, pudiéndose entender que el periodismo está mutando continuamente para entender lo que la población le demanda. Tampoco son las "posverdades, ${ }^{5}$ estupideces, chantajes religiosos, salvajismo de género» (Rincón, 2017: 20) ni el «sensacionalismo de la tele y la farándula» (Rincón, 2017: 21) lo que el público exige siempre; pues estos intereses cambian permanentemente ${ }^{6}$ y son difíciles de identificar incluso para los propios medios de comunicación, los primeros interesados en detectarlos.

4. Recuérdese, por ejemplo, las prácticas de los antiguos sofistas griegos, los discursos del presidente norteamericano A. Jackson, o las apelaciones constantes al pueblo del político colombiano J. E. Gaitán.

5. A mi parecer, este concepto tan manido y popular, es un simple eufemismo del término «mentira».

6. Véase como ejemplo la escasa audiencia del programa de telerrealidad español Gran Hermano Revolution, reality-show presente en España desde inicios del siglo XXI, el cual nutre de contenidos a otros programas de la misma cadena; siendo la empresa la primera interesada en mantener este formato de negocio debido a su rentabilidad. 
Asumir la comunicación como un bloque homogéneo sin apenas flexibilidad es algo erróneo. Entender al periodismo pre-mutante como algo no cambiante, únicamente para ensalzar una nueva propuesta de periodismo con unas virtudes que el modelo tradicional ya poseía, es, por lo tanto, errado.

\section{Conclusiones}

Desde mi punto de vista, el artículo titulado Periodismo mutante y bastardo es una llamativa comparación entre la docilidad canina y las relaciones empresariales y políticas presentes en el mundo periodístico, que si bien siempre estuvieron presentes, en la actualidad son más visibles para la sociedad general, gracias en parte a las nuevas tecnologías de la información. Respecto al nuevo periodismo que propone el autor, éste se basa únicamente en contradicciones y respuestas circulares que no dan respuesta a las problemáticas en las que se encuentra el sector, tales como el desempleo creciente entre los profesionales del gremio o la feroz competencia de las nuevas tecnologías.

Me atrevo a pronosticar que en futuros años, serán las redes sociales las que claudiquen ante los nuevos avances tecnológicos y el periodismo volverá a reinventarse de nuevo, como hizo durante toda su historia. Es así como surgirá un presunto nuevo periodismo, que de novedoso tendrá únicamente su nombre. 